\title{
CUERPO VEGETAL Y VIOLENCIA FECUNDADORA EN LAS FUENTES COLONIALES ANDINAS
}

En este artículo queremos mostrar algunas aproximaciones a los conceptos asociados al cuerpo desde la documentación etnohistórica y los primeros lexicones para lenguas indígenas producidas en los Andes. Intentamos, de esta manera, acercarnos a las nociones que podrían haber estado funcionando en las lenguas indígenas del tiempo de la Conquista. El trabajo con este material nos lleva a plantear que el sistema de pensamiento andino expresa una ontología andina del cuerpo en la que el ser humano y sus categorías fundamentales se definen de manera similar a la de la naturaleza, entendiendo el cuerpo humano como una planta y la reproducción agrícola como la reproducción humana. Por otro lado, se revisa el papel que juega la violencia, en la incorporación de los poderes genésicos de un vencido en contextos como guerra y agricultura.

Palabras clave: Andes, cuerpo, violencia, fertilidad, Colonia.

In this article we show some approximations to the concepts related to body from the first ethnohistorical documentation and lexicons for indigenous languages produced in the Andes. We try, in this way, closer to the notions that might have been operating in the indigenous languages of the time of the Conquest. Working with this material leads us to consider that the system of Andean thought expresses an Andean ontology of the body in which the human being and its fundamental categories are defined similarly to the way of nature, understanding the human body as a plant and agricultural reproduction as human reproduction. On the other hand, the role of violence in the incorporation of a full reproductive powers of the defeated ones in war and agriculture contexts.

Keywords: Andes, body, violence, dictionary, fertility, Colony.
El cuerpo es una construcción simbólica [...]

Nunca es un dato indiscutible, sino el efecto de una construcción social y cultural

(Le Breton 1990: 14).

En 1571, un grupo de indios toma prisionero al sacerdote agustino fray Diego Ortiz, acusado del asesinato por envenenamiento de Tito Cusi Yupanqui, uno de los últimos Incas resistentes en Vilcabamba. El calvario de Ortiz en Vitcos dura varios días y está marcado por una serie de vejámenes en una larga caminata hasta el bastión incaico de Vilcabamba, donde finalmente es ejecutado. Así lo describió Juana Guerrero el 11 de marzo de 1595:

Hasta que habiendo llegado a Marcanay, habiéndole arrastrado, le dieron con un hacha en el cogote y le mataron $y$ le enterraron en un hoyo, la cabeza para abajo y los pies arriba; y le metieron un palo de palma por el sieso; y habiéndole enterrado, le echaron encima corpa $y$ helecho $y$ chicha colorada; que es ceremonia y rito que ellos usaban; [...] y después vio esta testigo que de los hábitos y ropa del dicho padre hicieron partición los dichos indios; y conoció algunas chuspas que traían los indios hechas del dicho hábito, [...] y que lo llevaron después a donde dicen la Horca del Inca; y lo vendieron [sic] en el suelo, y lo pisaron (Bauer et al. 2014: 84, énfasis nuestro).

A Carla Díaz, proyecto fondecyt 1130431, Universidad Bernardo O’Higgins, Centro de Estudios Históricos, Museo Chileno de Arte Precolombino, Santiago, Chile, email: csdiaz@uc.cl 
El relato sobre la muerte de Diego Ortiz abre ciertas interrogantes; más que su muerte, producida por un golpe en el cuello, resulta particular el tratamiento del cuerpo post mortem. El sacerdote es enterrado, pero no de cualquier forma. Se cava un hoyo en el que es depositado el cadáver "la cabeza para abajo y los pies arriba" y, además, existe una clara voluntad de que el cuerpo quede fijo sobre la tierra, pues el palo que se le entierra por el ano da firmeza a esta postura. Pero el rito no acaba allí, los restos dispuestos de este modo son fertilizados con chicha y salitre; ${ }^{1}$ podemos pensar en un cuerpo plantado, sembrado en la tierra después de su muerte. Es la metáfora agrícola la que podría estar funcionando tras las operaciones llevadas a cabo con el cuerpo del otro, del otro enemigo. ¿Qué discursos produce esta práctica?: ¿es acaso una advertencia sobre las consecuencias de atentar contra un Inka?, ¿podríamos asimilarlo a la práctica europea de exhibir la cabeza del enemigo en una pica a modo de escarmiento, como ocurrió con la cabeza de Gonzalo Pizarro expuesta en la plaza de Lima en 1548 después de ser condenado a muerte por desafiar el poder de la Corona? (Hemming 2005). Tal vez el mensaje es otro: sembrar el cuerpo ¿para qué?, ¿para obtener frutos?

Pero volvamos por un momento al relato sobre la muerte y enterramiento de Ortiz. Según la descripción de Juana Guerrero, los indios utilizaron la ropa del sacerdote para confeccionar chuspas. Se habrían apropiado de su hábito para recomponerlo en un producto cultural andino, como son estas bolsas para transportar distintos elementos. El vestuario del otro se incorpora al universo material de los participantes de la ejecución, a partir de la transformación de un bien cultural ajeno en uno propio. Finalmente, estas chuspas, compuestas con el hábito del padre, son tendidas en el suelo y pisoteadas como símbolo de dominación. ${ }^{2}$ Esta dominación e incorporación de los bienes del otro funcionaría también con su cuerpo, ya que los procedimientos post mortem operados sobre Ortiz lo podrían transformar en una planta cultivada. Si esto es correcto, ¿de qué manera concibe el pensamiento andino el cuerpo humano que permite su siembra?, ¿existían términos específicos, ideas o valores que definieran el cuerpo humano en las lenguas indígenas del tiempo de la Conquista y que nos permitan comprender esta práctica? En este artículo nos guían dos objetivos: primero, proponer que el pensamiento andino entendió el cuerpo humano como un cuerpo vegetal; y segundo, que la reproducción del cuerpo vegetal enemigo está mediada por la violencia.
Para desarrollar el primer cometido y aproximarnos a posibles nociones y concepciones andinas del cuerpo humano, exploraremos el vocabulario anatómico contenido en los primeros lexicones coloniales de las lenguas generales quechua y aymara. ${ }^{3}$

\section{EL CUERPO VEGETAL EN LOS LEXICONES TEMPRANOS QUECHUA Y AYMARA}

El vocabulario anatómico contenido en los primeros diccionarios quechuas revela estrechos vínculos entre términos para nombrar distintas partes del cuerpo y ciertas plantas. En esta lengua, encontramos correspondencias que asocian a los humanos con el reino vegetal. Por ejemplo, el término songon, songo o soncco en los tres diccionarios quechua tempranos corresponde a la voz que designa una entidad corporal que reúne los órganos internos como corazón, entrañas, estómago, así como el juicio, la memoria y el entendimiento. Pero es también la expresión empleada para nombrar el corazón de la madera.

Las correspondencias vegetales se encuentran también en los pelos: el término pullu refiere al cabello o vello de personas y aves: "Pullu, pelo, o cosa peluda o vello o plumas menuditas" (Anónimo 1951 [1586]: 72). A su vez, pullu es la raíz del término pullullulluni, que significa "heruir la olla, o manar el agua" (Anónimo 1951 [1586]: 72), mientras que llullu se traduce como "pimpollo de arbol blando, o otra cosa blanda assi" (Santo Tomás 1951 [1560]: 311), "pimpollo ${ }^{4}$ o cosa tiernezica, como tallos" (Anónimo 1951 [1586]: 56) y aun: "Llullun. Los tallos o hojas tiernas, o verdes antes de endurecerse o secarse" (González Holguín 1989 [1608]: 217). Al parecer, los cabellos se comprenden como vellos que emanan o brotan, pero estos pelos serían también hojas verdes o tallos tiernos de los árboles que brotan antes de "endurecerse o secarse".

Ahora bien, la asociación no acaba ahí: en quechua, vllu es además "el miembro genital de cualquier animal macho", incluido el hombre (Anónimo 1951 [1586]: 88). Desde la entrada en español, tenemos: "Vergüenzas del hombre: ppencay, o vllu" (González Holguín 1989 [1608]: 691) y: "Verguenzas de hombres, vllu" (Anónimo 1951 [1586]: 198). Sin embargo, existe una palabra con la misma raíz que denota una especie de papa: "Vllucu. Ciertas rayzes de comer como ocas" (González Holguín 1989 [1608]: 354). El ulluco ${ }^{5}$ es un 
tubérculo parecido a la papa pero más pequeño, que se cultiva en la puna de los Andes; de ahí que la asociación de vllu con esta especie parezca significativa a la hora de pensar en posibles vínculos de los genitales con los vegetales y con la reproducción agrícola, así como con el espacio interior, o lo interno. Esto último se expresa en otro término corporal, la palabra que refiere a los testículos: coruta. Coruta también guarda relación con elementos de la tierra, con lo que está enterrado: "Vergüenzas de varones Coruta" (Santo Tomás 1951 [1560]: 225); "Corota, turmas" (Anónimo 1951 [1586]: 26). La palabra que designa la castración en quechua es corani; "Castrar, capar" (González Holguín 1989 [1608]: 450), "Corani.gui. capar, o castrar generalmente" (Santo Tomás 1951 [1560]: 270). Como es de esperar, el corte de los testículos está asociado también a la "castración" de plantas, corani.gui. es la misma palabra que señala el desentierro de un árbol "Corani.gui, o azpini.gui. escaruar arboles".

Estos antecedentes permiten vincular los órganos reproductores masculinos con la tierra y lo bajo, pero además involucran una dimensión que atañe a elementos agrícolas. Es esta dimensión la que quisiéramos explorar, pues parece relevante a la hora de entender la reproducción humana.

En quechua, yumacuni significa "engendrar el varon generalmente" o "emittere semen tantum". Yumay es la esperma secretada por el hombre, - "simiente de varon, o de qualquier animal"-, pero también es "el aguijón de la abeja", haciendo referencia a lo que se entierra y pica: "Yumaycun. Picar" (González Holguín 1989 [1608]: 371). Al parecer, la fecundación masculina se entiende como la producción de la semilla a través del pene que se entierra y expulsa el semen. En estrecho vínculo, vrua es el "varón estéril, que no engendra” (Santo Tomás 1951 [1560]: 372), "Vrhua, varon impotente” (Anónimo 1951 [1586]: 89); y también corresponde al término que designa un "[á]rbol infructífero, urhua, vpa hacha" (Anónimo 1951 [1586]: 113): (hacha es "árbol" y vpa “incapaz", "inhábil”).

Haciendo un recuento de lo expuesto hasta ahora a partir de la información de los diccionarios quechua, encontramos que el aparato reproductor masculino, vllu - coruta, se relaciona con lo interno, con el suelo, con lo que se introduce, en especial por su asociación con el ulluco y los árboles que se desentierran. Dicho vínculo sería posible en virtud de la relación conceptual entre la reproducción de plantas y la reproducción humana, la que se haría más evidente por la asimilación entre el hombre infértil y el árbol impotente.

Un elemento a considerar, pero que no surge directamente de las expresiones corporales, es el término "semilla". A primera vista, podría parecer una metáfora más o menos común para hacer referencia al semen o al óvulo. Sin embargo, es relevante para esta discusión porque en la lengua quechua está emparentado con el término "ancestro". En el diccionario Anónimo (1951 [1586]: 57), mallqui aparece como "planta cualquiera", de donde: "Mallquini, plantar". Mientras que el Lexicón (1951 [1560]: 314) ofrece: "Mallqui o mallquina planta para plantar" y "Mallquiçapiyoc planta con rayz y tierra". Por su parte, González Holguín (1989 [1608]: 224) registra "Mallqui. La planta tierna para plantar", "Qualquiera arbol frutal" y "Mallquini. Plantar, o trasplantar". En definitiva, los tres diccionarios quechua relacionan mallqui con la semilla, pero sabemos también que mallqui hace referencia a los ancestros, relacionando a los antepasados con las plantas o semillas para plantar. Si esto es correcto, la semilla humana sería mucho más que una metáfora sobre la reproducción. Volveremos sobre esto más adelante.

En cuanto a los genitales femeninos, encontramos el término raca, que es también el contenedor de la orina en la mujer. Esta idea de contenedor se encuentra en las palabras con la raíz raca: "Racani.gui edificar pared de piedra” (Santo Tomás 1951 [1560]: 345), "Racay. Corral; Racay racay. Corrales, o pueblo despoblado" (González Holguín 1989 [1608]: 311). Al parecer, el contenedor tendría características de hendidura o apertura que contiene, pues racay no solo es pueblo despoblado, también es el sinónimo para "Cavallillo entre era o sulco" (Santo Tomás 1951 [1560]: 345): un cavalillo es una zanja o canal que separa terrenos. Es posible entonces que los genitales femeninos se comprendan como una apertura que tiene capacidad de contener, contener el vllu que se entierra y expulsa yumay, el semen masculino. Ahora bien, la relación de los genitales femeninos con la tierra no se restringe solamente a la zanja que divide o contiene. Raca también funciona como la raíz del nombre de un tubérculo: "Racach $a,{ }^{6}$ cierta rayz como turma de tierra" (Anónimo 1951 [1586]: 76).

En suma, los antecedentes expuestos permiten proponer que, desde el quechua, los órganos reproductores femeninos y masculinos están vinculados a las plantas, al interior de la tierra y a las prácticas agrícolas. Además, los nombres de ambos genitales se hallan en la raíz de 


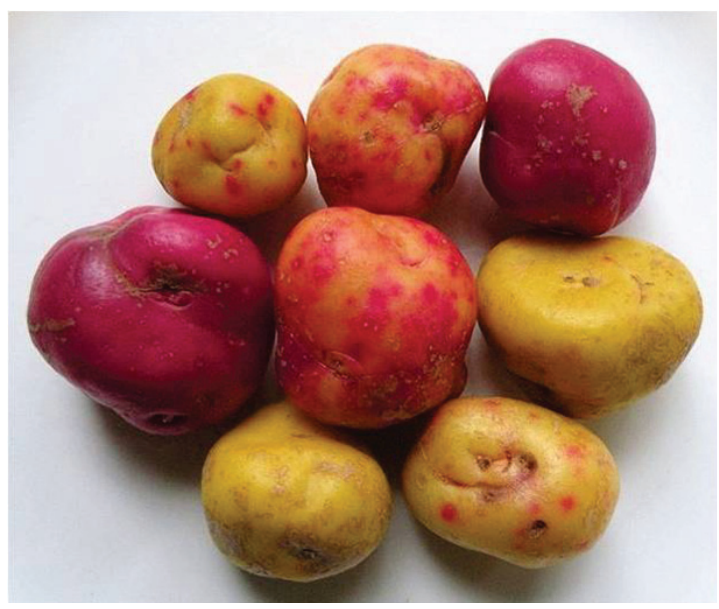

Figura 1. Ulluco o papa lisa, tubérculo andino originario. Figure 1. Ulluco ("smooth potato"), native Andean tuber. $<$ http://commons. wikimedia.org/wiki/File:Ulloco.jpg> [Consultado 1-11-2016].

términos que denominan especies alimenticias precisas, como los tubérculos ulluco y racacha. Ulluco para el pene o vllu, y racacha para la vagina o raca. Ambos tubérculos, parientes de las papas, son originarios de los Andes, y parte de los alimentos producidos y consumidos por los andinos hasta hoy (figs. 1 y 2). Por otra parte, el proceso de reproducción humana, se entendería conceptualmente o se asimilaría al proceso de reproducción agrícola. El hombre que entierra el pene en la apertura, que es la vagina, y desprende su semilla, la cual se aloja en la apertura contenedora que luego permitirá la salida, por la misma apertura, del brote de la semilla.

Ahora bien, si se considera la lengua aymara, encontramos el término chuyma, que denomina el corazón, el estómago " $y$ casi todo lo interior del cuerpo", y que además resulta ser el mismo para nombrar "el corazón de los árboles y otras cosas como de las frutas" (Bertonio 1984 [1612]: 94). La palabra que designa el rostro en aymara es ahano, semblante, aspecto, figura, cara y rostro de los hombres y animales: "La haz de todas las cosas", "Media buelta de lo que vno texe", y es también "La espiga de la quinua". Una persona muda se denomina $a m u$, aunque amu no significa solo mudo, sino también "Boton de la flor” (Bertonio 1984 [1612]: 17). Una flor que está en botón es una flor cerrada, que no ha crecido lo suficiente como para poder abrirse o hablar. Para los cabellos, desde la entrada en español encontramos: "Pelo, vello blando de los animales, y paxaros, y hombres: Phuphuu, Koña koña, Phuñu", pero phuñu se usa también para

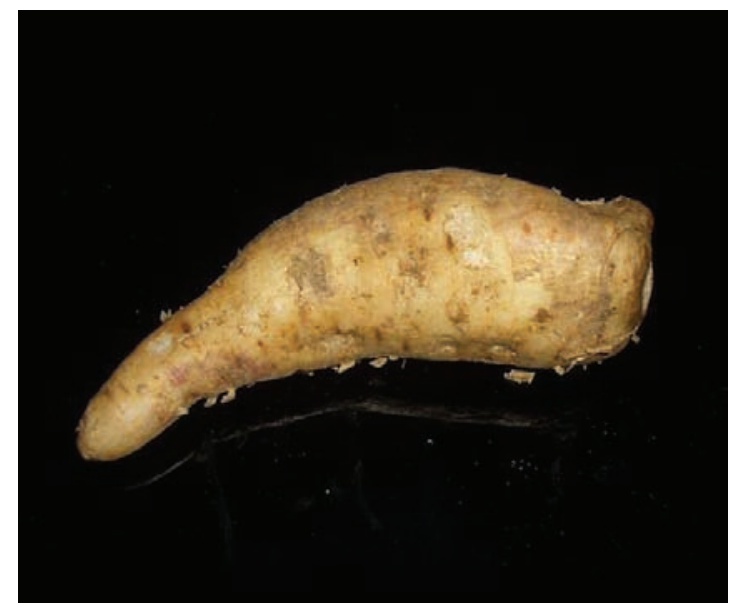

Figura 2. Racacha o zanahoria blanca, también originaria de la zona andina. Figure 2. Racacha ("white carrot"), also native to the Andes. <http://lamula.pe/files/2009/09//95782465d54a510023c2 35ba3004be49.jpg > [Consultado 1-11-2016].

denominar el "Cabello de la mazorca de maíz: toncona phuñupa” (Bertonio 1984 [1612]: 106).

Los términos de los genitales masculino y femenino son allu, yoca y chenque, respectivamente. Allu y yoca corresponden a los genitales masculinos, pero yoca también es el hijo varón (Bertonio 1984 [1612]: 396). Para los testículos, las voces son "amca, macco, macoora, korota". Amca, además de testículos, refiere a la papa: "Papa, comida ordinaria destos indios", y a la cebolla que usan las mujeres: "Vnas como cebollitas, con cuyo çumo se dereçan el cabello las indias" (Bertonio 1984 [1612]: 15). Al igual que en quechua, hay aquí asociaciones con la agricultura, papas y "cebollitas". Los vínculos con lo agrícola están presentes también en el semen del hombre, que es asimismo el de los animales y las plantas: hatha es "semilla de las plantas y los hombres y los animales", pero también es "casta, familia, ayllo" (Bertonio 1984 [1612]: 124), mientras que hathasitha es engendrar la semilla. Un término sinónimo de semen en aymara es sapaca, término directamente relacionado con las plantas, lo que resulta relevante al pensar la reproducción humana: "Sapa, La raíz de las plantas, y tuno [sic] es donde nace la raíz", "Sapatatatha echar raíz las cosas plantadas o sembradas" (Bertonio 1984 [1612]: 309). A la luz de lo expuesto, encontramos que los órganos reproductores masculinos -yoca, hatha-sapaca- se asimilan a las plantas, pero además se conectan con la familia, con el ayllu entendido como la raíz de las personas y de los hijos. 
Del lado femenino, chenque es la vagina de la mujer, mientras que la semilla o semen mulieris corresponde a llausa llausa o hanko. Hanko, además de la semilla de la mujer, es también blanco, y hanko yapu es “Tierra fértil" (Bertonio 1984 [1612]: 118). El término llausa corresponde a "baua y tambien semen mulieris" (Bertonio 1984 [1612]: 203). Su raíz -llau-parece especialmente importante para entender la forma de concebir la reproducción humana. "Llau: Vna manera de orilla o repulgo en las mantas o mantos". Esta idea de orilla se relacionaría con el borde del espacio que se puede abrir y cerrar, pues llau se halla igualmente en términos que aluden a esos conceptos: "Llauitha: Cerrar juntar la puerta sin llaue o con ella", "Llauiratha: Abrir la puerta de par en par, o abrir con llaue, o desatapar algo" y "Llauintatha: cerrar algo dentro" (Bertonio 1984 [1612]: 203). Al parecer, en torno a la semilla femenina hay también conceptos de espacios que pueden contener y que además tienen bordes, una apertura con capacidad fertilizante. Esto último se puede adviertir en el término que denomina la placenta de la mujer. Cchihua es "las pares de la mueger", 7 pero también "yeruas de comer cozidas" (Bertonio 1984 [1612]: 84). Cocinar implica una conversión, el cambio de una "yerua" cruda a una cocida. Tal proceso de transformación se encuentra en el término cchihua, "Cchihuacaquikhatha: mudar el color del rostro", "Cchihuaquiptatha: demudarse" (Bertonio 1984 [1612]: 84). Da la impresión de que la mujer posee la capacidad de transformar la semilla, de "cocinarla" para generar un hijo. Esta idea de hijo-semilla se puede intuir en el término que nombra la semilla de quinua degenerada-isualla-, el mismo que se destina a los hijos naturales: "Y aun llaman deste nombre a los bastardos, y a los que no son legítimos" (Bertonio 1984 [1612]: 428), "Isualla: Hijo adulterino" (Bertonio 1984 [1612]: 183).

El aymara vincula los órganos reproductores a los vegetales y al espacio de abajo, a lo interior. Ello se aprecia en la asociación con las papas y las cebollas, pero además hay una dimensión de consanguinidad en las semillas masculina y femenina, al entenderlas como la raíz de las personas. Junto con esto, la reproducción humana se asimila a de las plantas, en que la tierra corresponde a la mujer fértil, único recipiente capaz de transformar la semilla en un hijo.

De todo el material presentado sobre las conceptualizaciones corporales andinas contenidas en los lexicones coloniales surgen algunas ideas a considerar. Nos encontramos frente a un material que muestra un sistema de pensamiento que define al ser humano y sus categorías fundamentales de manera distinta al sistema cristiano-occidental. ${ }^{8} \mathrm{Al}$ parecer, hay una ontología andina de los humanos que no los diferencia de la naturaleza, mientras que la judeocristiana los entiende separados del medio ambiente o del mundo que habitan. Así, la noción de persona que estaría en juego es la del humano entendido como una planta y la reproducción agrícola como la reproducción de las personas. Las correspondencias que se encuentran en la lengua respecto al cuerpo y sus vínculos con entidades de la naturaleza nos llevan a proponer que las sociedades andinas de la colonia temprana, dentro de su visión del mundo, definen, valoran y le dan sentido al cuerpo humano (Le Breton 1990) como un cuerpo vegetal.

El vocabulario anatómico de los lexicones ofrece correspondencias según las cuales el cuerpo humano es otra forma vegetal, en que las plantas, los árboles, los frutos, las semillas y sus procesos generativos se corresponden con la anatomía y reproducción humana. El cuerpo humano concebido como planta se encuentra en varios términos comunes y compartidos por ambas entidades, como el rostro humano que es la espiga de la quinua; los cabellos o pelos, asociados a los tallos tiernos o a las hojas verdes; el songo-chuyma humano, nombre del corazón-centro de la madera, los árboles o las frutas. La asociación con los árboles se encuentra asimismo en el árbol infructífero o incapaz que es igualmente el hombre infértil; por otro lado, el corte de los testículos del hombre es también la castración del árbol, su desentierro. Pero las correspondencias no solo atañen a los árboles; el ulluco y la racacha, ambos tubérculos comestibles originarios del altiplano andino, aparecen asociados a los órganos reproductores masculinos y femeninos respectivamente. De hecho, la vagina femenina, comprendida como una apertura contenedora, es análoga a la tierra fértil o hanko yapu. Asimismo, las papas y las cebollas se relacionan con los testículos o amca. Por último, que los hijos se entiendan como semillas fertilizadas y que estas hagan alusión a la raíz de las plantas, al ayllu y a los ancestros, parece relevante para establecer las equivalencias existentes entre el cuerpo humano y los vegetales.

Adicionalmente, la correspondencia entre reproducción humana y reproducción de plantas se observa en las asociaciones en que la mujer, asimilada a la tierra, es entendida como la apertura o recipiente capaz de contener el semen del hombre, quien entierra el 
vllu, como el aguijón de la abeja, y deposita la semilla en su interior. Mientras que es la mujer quien tiene la capacidad transformadora, de "cocinar" y cambiar el estado del semen, pues fertiliza y convierte la semilla en un hijo del ayllu, de la raíz de las personas, la familia. $\mathrm{Al}$ respecto, parece interesante revisar la propuesta de Le Breton sobre las concepciones del cuerpo. El autor señala que "las representaciones del cuerpo y los saberes acerca del cuerpo son tributarios de un estado social, de una visión del mundo y, dentro de esta última, de una definición de la persona. El cuerpo es una construcción simbólica, no una realidad en sí mismo. De ahí la miríada de representaciones que busca darle un sentido y su carácter heteróclito, insólito, contradictorio, de una sociedad a otra" (Le Breton 1990: 13-14).

Así, la traslación de conceptos e imágenes entre el cuerpo humano y su reproducción y las plantas con sus procesos genésicos no serían posibles si ambas entidades no se entendieran como iguales, como símiles la una de la otra, si no participaran de una misma esencia. De hecho, las correspondencias entre árbol infructífero y hombre estéril, o tierra fértil y semilla femenina, tampoco se comprenderían si no se correspondieran en el sistema de pensamiento andino. Los vínculos entre el cuerpo y las nociones vegetales en el vocabulario anatómico colonial no nos hablan de una metáfora, sino de una identidad de sustancia, común y compartida entre ambas entidades.

La traslación o comparación de expresiones entre el cuerpo humano y los vegetales se pueden percibir en otras sociedades. Sin embargo, la asimilación es de otro tipo. El sistema occidental, por ejemplo, establece asociaciones metafóricas por semejanza entre ambos; la relación semántica que permite la sustitución de los términos se basa en la comparación de formas, de características comunes en cuanto a apariencia. Por ejemplo, la frecuente asociación de los órganos reproductores femeninos con moluscos o mariscos, o del pene con vegetales como el nabo, la banana, etc. Por el contrario, en el sistema de pensamiento andino, la relación de términos entre ambas entidades muestra una identidad de sustancia común. El cuerpo humano no es solo conceptualizado como un vegetal, sino que es un vegetal. Aun cuando hemos extraído esta interpretación del análisis de los lexicones, existen también otros indicios coloniales que, al parecer, la apoyarían.

Enrique González (2003) ofrece un dato muy sugerente acerca del Archivo Arzobispal de Lima para finales del siglo XVII (1690). Da cuenta del proceso contra una mujer, Josefa de la Tica, quien es sorprendida realizando un rutuchico a su hija: "poniendo una hijita suya sobre una mesa y haciéndole cortar el cabello por los visitantes, quienes depositaban sus obsequios en una palangana, $y$ que tenían la creencia de que era necesario tal corte para impedir que la niña se quedara tullida (González 2003: 69-70, énfasis nuestro). El rutuchico es una ceremonia de pasaje por la cual el niño(a) se incorpora a la vida social de la comunidad a la que pertenece mediante el primer corte de cabellos y uñas y recibe no solo un nombre sino también las prendas de vestuario identitarias de su comunidad. Acontece alrededor de los dos años de vida, en el momento del "destete".

La idea de "impedir que la niña se tulla" a través del corte del cabello, es concordante con la poda de plantas, ya que permite su crecimiento, en este caso, que el nuevo miembro del grupo madure y se desenvuelva en sociedad. En esta línea, Isbell (1997) aporta un dato etnográfico relevante. Los andinos habitantes de Chuschi, en el Departamento de Ayacucho, Perú, conciben el ciclo de vida de las personas, desde el nacimiento hasta la muerte y el más allá, en analogía con el crecimiento de las papas y su conversión en chuñu. Los niños, que nacen inmaduros, van madurando como la papa, hasta convertirse en ancianos o chuñu, papas deshidratadas, secas.

Pero volvamos a la información colonial. Joan de Santa Cruz Pachacuti entrega otra referencia interesante, ahora sobre el surgimiento de un árbol. En efecto, cuenta que el capitán Uillca Quire se transforma en árbol medicinal después de ser muerto en combate. Uillca, preocupado por morir "sin aber hecho ningún fruto", dice: “['] Aquí queda y deja el cuerpo'. Y les haze que enterrase junto un árbol y que los cavase al tronco de la madera para meter a todo su cuerpo en ella. Y les dize que el grano que echare el árbol sería medicina llamado uillca y que los echaría todos los males humures $y$ cóleras" (Pachacuti 1993 [1613?]: 220, énfasis nuestro).

Pero no es el único origen de plantas a partir de seres humanos. ${ }^{9}$ En esta misma línea se encuentra el mito recogido por el padre Antonio de Calancha, que explica la aparición de las plantas alimenticias en la costa norcentral del Perú a través del descuartizamiento, por parte de Pachacamac, de un recién nacido. En el inicio del mundo no existían los alimentos para mantener a la única pareja de seres humanos que vagaba famélica en busca de subsistencia. El hombre muere de hambre 
y la mujer, que queda sola, se queja ante el sol por su miseria. Luego, este se compadece, con sus rayos la fecunda y a los cuatro días nace un niño.

Pachacamac, indignado de que un hijo del Sol le quitase la adoración que se le debía rendir sólo a él, cogió al recién nacido y sin oír los gritos de la madre, despedazó a la criatura. Luego, para que la mujer no se quejase al Sol por la falta de subsistencias, sembró los dientes del infante y de ellos brotó el maíz; de las costillas y huesos surgieron las yucas y todas las demás raíces de la tierra; de su carne brotaron pepinos, pacaes y demás frutas y árboles. Desde entonces desapareció el hambre (Rostworowski 1992: 27, énfasis nuestro).

El relato muestra un elemento importante: el cuerpo despedazado de un niño permite el surgimiento de las plantas alimenticias. Es una muerte repentina, violenta. El pequeño es separado de su madre, que grita y se lamenta, mientras observa cómo la divinidad destroza el cuerpo del recién nacido y lo siembra. Sin embargo, este no es el único origen de plantas comestibles asociado al descuartizamiento de personas que se halla en los textos coloniales. Existe aun otro dato, del siglo XVI, que da cuenta del nacimiento de la coca a partir del acto de romper el cuerpo de una mujer:

Que dicen quentre los naturales se trataba que la dicha coca antes questuviese como agora esta en arboles, era mujer muy hermosa, y que por ser mala de su cuerpo, la mataron y la partieron por medio y della había nacido un arbol al cual llamaron mama coca o coca mama, y que desde allí la comenzaron a comer [...] y que muchas pallas ha habido y hay que por esta causa se llamaron Coca, y questo lo oyeron decir a sus pasados [...] decían que era el origen de la dicha coca" (Ruiz de Navamuel 1904: 182-183).

Estos mitos guardan elementos reveladores. Por una parte, los miembros del cuerpo de una persona se pueden sembrar para generar plantas (nuevamente encontramos el cuerpo humano-vegetal); y por otra, instalan un nuevo elemento a considerar, que corresponde al segundo propósito de este artículo: el rol que en estas transformaciones vegetales podría desempeñar la violencia sobre el cuerpo.

En los relatos revisados, la transformación del cuerpo en alimento está mediado por un acto de violencia sobre él: la divinidad destroza al niño para generar las plantas, los hombres a la mujer para el nacimiento de la coca. La muerte no acontece por causas naturales, como una enfermedad, por ejemplo, sino que es repentina y causada por otro, por fuerzas externas que agreden al cuerpo. Esta agresión, que resulta fecundadora, podría encontrarse en la base de la transformación del cuerpo en vegetal de consumo; sin ella, tal vez la creación de los alimentos no habría sido posible, ni tampoco la conversión del guerrero Uillca Quire en árbol medicinal. Esta idea de violencia fecundadora podría estar tras el conjunto de decisiones y procedimientos en torno al tipo de entierro que recibe Diego Ortiz en 1571.

En este punto, la información etnográfica puede aportar a la discusión. Verónica Cereceda (comunicación personal) comenta que las pukaras (especies de altares de varios metros en forma de escalera cubiertas por flores, globos, serpentinas y todo tipo de alimentos, como frutas, panes, carne cruda, botellas de alcohol, frutas, verduras, etc.) que se levantan para carnavales en las comunidades actuales de Tarabuco-Yampara, están dedicadas a los muertos, pero solo a los muertos de muerte violenta, repentina, fuera de sus hogares, accidentales. Ello se debe a que estas almas estarían directamente vinculadas a la fertilidad agrícola y a la fecundidad ganadera. Asimismo, el carnaval coincide con un período importante del año agrícola: el del surgimiento de las primeras plantas. En su trabajo de campo con la comunidad Tarabuco en Bolivia, sobre la música al Tata Pujllay en tiempos de carnaval, R. Martínez (2010) informa que a los pies de las pukaras se instalan unas pequeñas cruces de madera - "alma-cruz"10 - que representan el espíritu de las personas muertas, como se acaba de especificar, de manera violenta. "Cada almacruz evoca precisamente a un muerto y lleva pintado su nombre. Durante la celebración de la pukara la gente se dirige a las cruces hablándoles, invocándolas por su nombre, challando abundantemente y pidiéndoles protección para los viajes, ayuda para la cosecha y la reproducción del ganado" (Martínez 2010: 146).

Por otra parte, los tinkus o batallas rituales cuentan con una importante dimensión agrícola (Allen 1988; Topic \& Lange 1997; Platt 2010). Para la fiesta del 3 de mayo, los Macha realizan un tinku bajo la presencia de los Tata Wilakrus o "Padre Vera Cruz", cruces de madera de gran tamaño que se encuentran ubicadas en pequeñas capillas en los cerros cercanos a los pueblos (Platt 2010). Estas cruces, pintadas con símbolos de fertilidad para la fiesta del 3 de mayo, son vestidas con ropa de combate: poncho, casco de guerra, talega con coca y cinturón. "Cada cruz es cargada desde la estancia de turno a la iglesia de la parroquia en el hombro de un combatiente, en medio del grupo de guerreros locales 
con casco" (Platt 2010: 309). Después de oír misa, estas cruces de fertilidad con ropa de combate presiden la batalla ritual. En los tinkus, tanto el derramamiento de sangre como el desgaste de energía en el combate es fundamental, pues ellos alimentan a la tierra, que luego podrá devolver a los participantes su desgaste con productos agrícolas (Allen 1988).

Para desarrollar la propuesta sobre la violencia y los efectos fecundadores que tiene en los cuerpos vegetales de los otros enemigos, recurriremos a registros etnohistóricos, arqueológicos e iconográficos prehispánicos asociados especialmente a la decapitación. Esto se debe a dos razones fundamentales: la primera es descubrir si la información colonial analizada desde los lexicones y mitos cuenta con antecedentes durante el período de Conquista y antes de él, mientras que la segunda obedece a nuestras propias limitaciones de investigación: es el material que mejor conocemos y que nos permite analizar las posibles prácticas y usos de partes del cuerpo a la luz de las ideas que relacionan muerte violenta, fertilidad y cuerpos vegetales.

\section{CUERPOS DESMEMBRADOS: GUERRA Y AGRICULTURA}

Una primera aproximación desde las fuentes etnohistóricas nos lleva a advertir que en contextos de enfrentamientos y muerte violenta de un otro, el desmembramiento del cuerpo, especialmente el cortar la cabeza del vencido en batalla, era una práctica bastante corriente entre los andinos. Varios son los testimonios que la consignan, por lo que daremos cuenta tan solo de algunos. Cieza de León (1996 [1553]: 61) señala que cabezas obtenidas de los enemigos derrotados en batallas eran exhibidas en las casas de curacas o capitanes principales; sabemos también del uso de cabezas de enemigos como vasos para beber, como hizo Atawuallpa con la cabeza de Wascar (Fernández de Oviedo 1959 [1535]: 191). Guaman Poma cuenta que Auqui Topa Ynga Yupanqui, hijo de Capac Yupanqui, presentaba a su padre las cabezas de los enemigos derrotados para "que los uiese y se holgase de la uitoria de su hijo" (Guaman Poma (2008 [1615]: 154) (fig. 3). Por su lado, Joan de Santa Cruz Pachacuti hace una referencia a su uso en combates: "Las cabezas cortadas que estaban para este efecto hechas las untan en sangre de llamas y las ponen en las lanzas" (Pachacuti 1993 [1613]: 77).

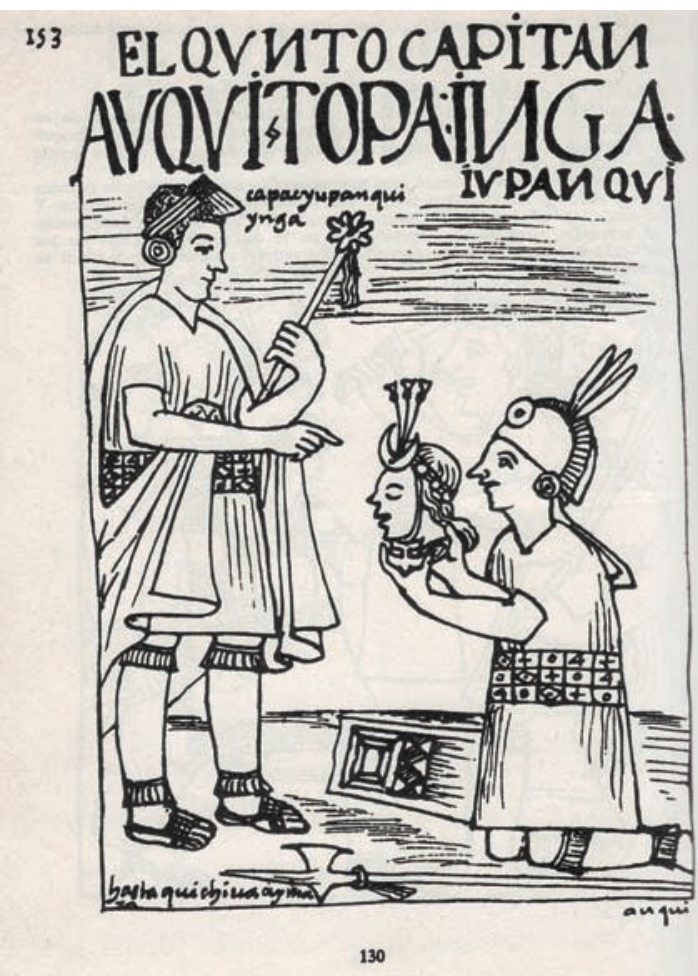

Figura 3. Guaman Poma "El quinto capitán Avqui Topa Inga" (Guaman Poma 1980 [1615]: 153). Figure 3. "Fifth Captain Avqui Topa Inga" (Guaman Poma 1980 [1615]: 153).

Si bien las prácticas documentadas por los cronistas aluden al uso de cabezas de enemigos derrotados como muestra de dominación, existen otros registros que apuntan a contextos rituales en que sacerdotes y divinidades celebran brindis, como lo describe Cieza de León:

\footnotetext{
Y si auían preso a algunos de sus comarcanos, con quien tuuiessen guerra o alguna enemistad, juntáuanse (según también quentan) y después de auerse embriagado con su vino, y auer hecho lo mismo del preso, con sus nauajas de pedernal o de cobre, el sacerdote mayor de ellos lo mataua: cortandole la cebeça, la ofrecían con el cuerpo al maldito demonio enemigo de natura humana (Cieza de León 1996 [1553]: 158, énfasis nuestro).
}

En Ritos y tradiciones de Huarochirí hay un dato interesante sobre el uso ritual de partes del cuerpo de un vencido, particularmente de las cabezas, que vale la pena revisar. Se refiere a una tradición del pueblo Checa, que usaba máscaras compuestas con los huesos de las cabezas de los enemigos capturados en las batallas revestidas con yeso, llamadas Huayos. ${ }^{11}$ De acuerdo al 
relato, la primera de estas máscaras fue obtenida de un héroe o antepasado llamado Ñamsapa, quien conquistó el territorio y posteriormente se transformó en wak'a: "Después, cuando capturaban a alguien en la guerra, le recortaban el rostro y, transformándolo en máscara, bailaban llevándolo puesto. Decían que de ello procedía su valentía" (Taylor 2008: 111). Sin embargo, esta no es la única práctica ritual realizada con los huayos, pues también formaban parte de ceremonias propiciatorias de fertilidad y fecundidad agrícola. Allí cumplían una función distinta, al participar de bailes y procesiones con el fin de asegurar la reproducción de personas, animales y plantas, en un ritual regido por las lógicas de reciprocidad andina (Taylor 2008: 111-113). Los huayos eran entonces objetos de sacralidad que actuaban en ámbitos diferentes: guerra y agricultura.

Da la impresión de que la obtención de cabezas de enemigos en contextos bélicos es una práctica que involucra apoderarse de un signo valioso y prestigioso, pero que a su vez permitiría obtener recursos benéficos y reproductores a través de la transformación de la cabeza ajena en propia. Veamos si desde la arqueología y el registro iconográfico prehispánico podemos encontrar otros elementos que nos permitan desarrollar esta impresión sobre los usos del cuerpo en los dos ámbitos enunciados arriba.

El registro iconográfico en los Andes prehispánicos es abundante en representaciones de desmembramientos y cabezas cortadas, y su primer antecedente se halla en la Cultura Sechín del Período Formativo (1600 AC-1200 AC) $)^{12}$ (fig. 4). La iconografía cerámica Moche (100 DC-700 DC) es profusa en imágenes de prisioneros decapitados o con sus cuerpos cercenados. Otro tanto se observa en Tiwanaku (100 DC-1200 DC), uno de cuyos ejemplos más conocidos es el de los personajes oficiantes de la divinidad central en la Puerta del Sol. Las referencias se multiplican hasta alcanzar una amplia y constante presencia en la zona centro y centro sur andina. ${ }^{13}$

Uno de los primeros contextos que muestra la revisión de la iconografía prehispánica se encuentra en torno a conceptos relacionados con la guerra, la derrota, la muerte violenta y la supremacía de unos sobre otros. Esto es especialmente claro en registros como Sechín o Moche, en que el sometimiento del vencido es parte de los signos más evidentes. Jiménez y Samaniego (1973: 33) interpretan el gran número de cabezas degolladas y partes de cuerpos cercenados de Sechín como testimonio del triunfo de un grupo vencedor sobre otro vencido. Algo

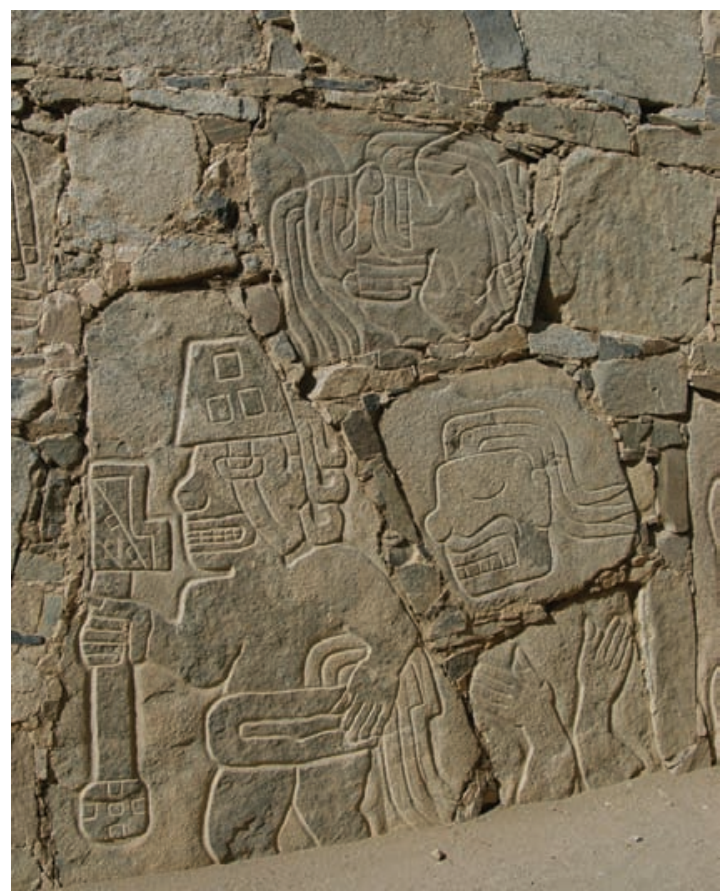

Figura 4. Personaje con báculo o arma, cabezas y partes del cuerpo (<http://www.flickr.com/search/?q=sech\%C3\%ADn\&f=hp >). Figure 4. Figure with staff or weapon, heads and body parts (<http://www. flickr.com/search/?q=sech\%C3\%ADneff=hp>).

similar ocurre con las escenas de la cerámica Moche, en que los descuartizamientos del derrotado se destinaban a la creación de trofeos (Alva \& Donnan 1993: 132) (fig. 5).

Ahora bien, los contenidos de fertilidad y fecundidad en el despedazamiento del cuerpo son reconocibles también en el registro iconográfico de distintas culturas andinas prehispánicas. Gallardo (1996), a través del estudio de la iconografía Nazca (figs. 6 y 7), ha notado la fuerte conexión simbólica entre dichos contenidos y la presencia de cabezas cercenadas, en una clara alusión a la vida que se genera a partir de la muerte, lo que es especialmente significativo en el personaje Ser Antropomorfo y en sus cabezas trofeo, de las que surgen plantas (Gallardo 1996: 39). En esta misma dirección, Frame plantea dos observaciones muy sugerentes sobre los fardos funerarios Paracas Necrópolis y su iconografía: por una parte, la estrecha relación entre cabezas, semillas y plantas, incluso la sustitución metafórica entre ambas entidades que se advierte en personajes como el Sacrificador (Frame 2001: 70); y por otra, el vínculo entre la fertilidad y los ancestros, ya que los textiles funerarios harían alusión a la constante transformación de un muerto 


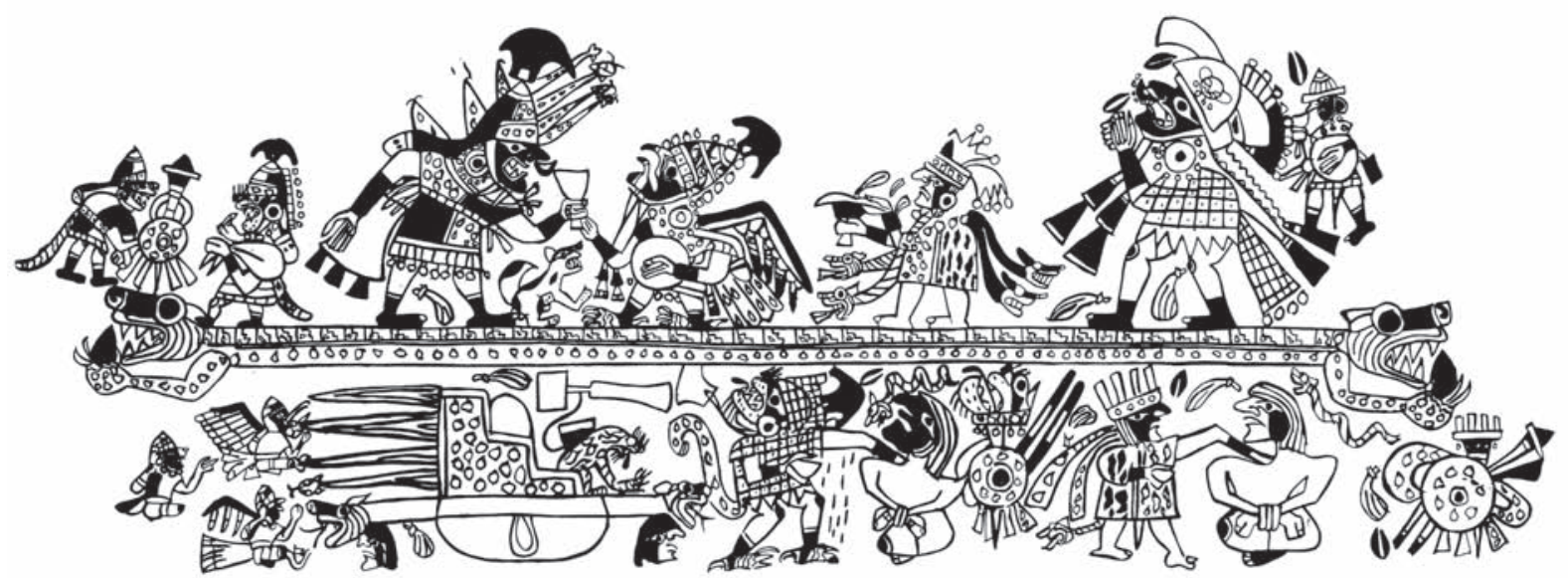

Figura 5. Arriba: Ceremonia de sacrificio de prisioneros; abajo: consumo de sangre (Alva 1993: 132). Figure 5. Top: Ceremony involving prisoner sacrifice; botton: drinking blood (Alva 1993: 132).

que, luego de atravesar distintas etapas de crecimiento, se convierte en ancestro cargado de poderes fecundadores. De hecho, la autora constata que uno de los fardos contenía en su interior un saco de $12 \mathrm{~kg}$ de frijoles negros en lugar de un cuerpo. Refiriéndose a los personajes sacrificadores presentes en la arquitectura Tiwanaku, Berenguer también advierte la relación entre miembros cercenados del cuerpo y rituales asociados a la fertilidad agrícola bajo la creencia de que los muertos cuidan los campos de cultivo y así aseguran buenas cosechas. ${ }^{14}$ Algo similar propone para las partes del cuerpo enterradas en la Pirámide de Akapana: "eran cortadas y plantadas en la tierra, de manera similar a como los campesinos cortan las 'cabezas' de las papas y las plantan para que surjan nuevos brotes. En otras palabras, los chamanes sacrificadores utilizaban a los muertos por sus poderes para dar vida" (Berenguer 2000: 32).

Al parecer, guerra y agricultura están íntimamente conectadas en el pensamiento andino. No hay que olvidar que las batallas guardan también una poderosa dimensión religiosa y agrícola (Platt 1987; Nielsen 2007). Desde la etnografía, vimos cómo funciona en el tinku, y pareciera que la relación entre fertilidad agrícola, guerra y muerte violenta atravesaría también la Colonia, e incluso dataría de mucho antes de la invasión.

\section{VIOLENCIA FECUNDADORA}

Para intentar comprender cómo los contenidos de violencia y fecundidad están presentes dentro de la

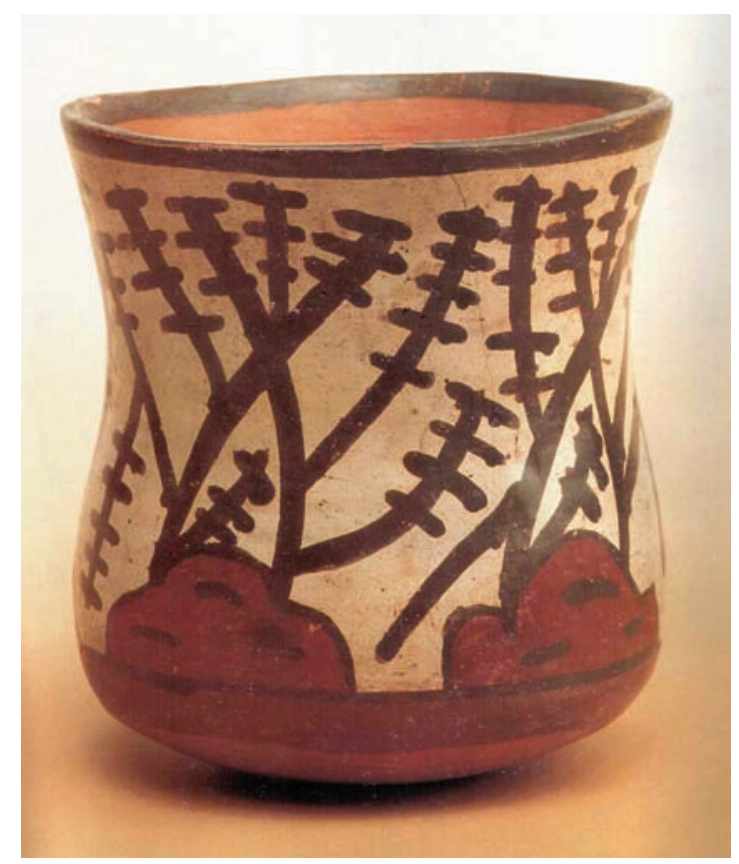

Figura 6. Nazca, cabeza-trofeo germinando un posible árbol (Colección de Carlos Cardoen, en Gallardo 1996). Figure 6. Nazca, trophy-head germinating what is possibly a tree (Carlos Cardoen's Collection, in Gallardo 1996).

guerra y la agricultura, resulta interesante la referencia de Garcilaso de la Vega (2005 [1609]: 255) sobre un tipo de canto, llamado hayllitha, que se realizaba para celebrar los triunfos en batallas, pero también para la siembra de los cultivos. La información que permite una mejor comprensión de esta correspondencia de sentido está en 


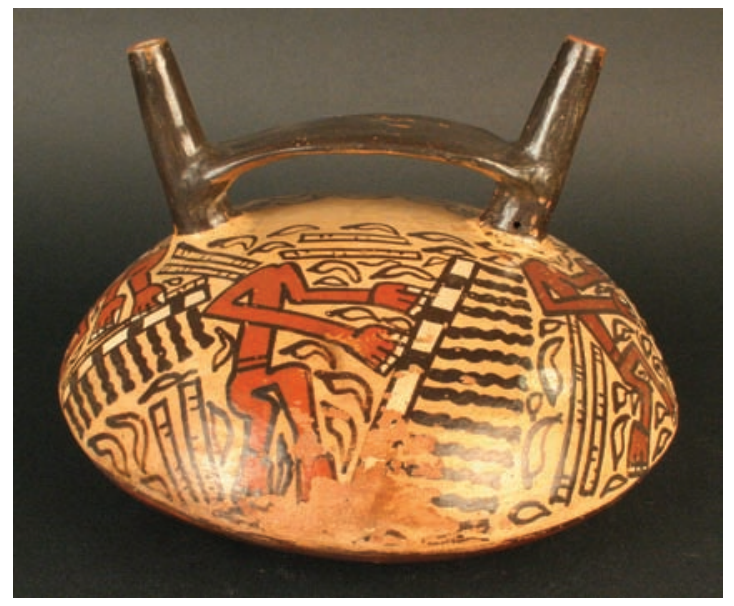

Figura 7. Nazca, botella asa puente con ronda de decapitados en tareas agrícolas (MChAP 0293, <http://www.precolombino.cl/ archivo/coleccion/area/andes-centrales/nasca>). Figure 7. Nazca, bridge-handled bottle with a band of headless figures engaged in agricultural work (MChAP 0293, at: <http://www.precolombino. cl/archivo/coleccion/area/andes-centrales/nasca $>$ ).

los lexicones. Desde el aymara, encontramos hayllitha: "Entrar con triunfo en el pueblo, alcançada que sea la victoria (Bertonio 1984 [1612]: 126). En quechua, hay definiciones en torno a canto y danza de triunfo sobre los enemigos, así como a la siembra terminada (Anónimo 1951 [1586]: 123, 43), pero también relacionada con la captura de un oponente (Santo Tomás 1951 [1560]: 290). Sin embargo, la referencia más interesante la entrega González Holguín: "Cantar de triunfo. Haylliy, y quando acaban la chacra que la vencen [...] Dançar cantando la victoria de la chacra que se acaba. Hayllicuni" (González Holguín 1989 [1608]: 471). Desde el quechua, "Haylli. Canto regozijado en guerra, o chacras bien acabadas o vencidas" (González Holguín 1989 [1608]: 157, énfasis nuestro). Nuevamente se observa la asimilación de las personas con los vegetales, pero esta vez desde actos culturales, prácticas sociales, como son la guerra y la agricultura. ¿Por qué categorías como guerra y agricultura podrían ser asimilables al punto que una misma práctica puede aludir a una o a otra, como se expresa en el canto-danza haylli?

Da la impresión que la relación entre guerra, muerte violenta y derrota de un contrario formaría parte de un sistema significativo en que regeneración, fecundidad y reproducción de personas, animales y vegetales están estrechamente ligadas. Sin embargo, la posibilidad de obtener los recursos productores estaría mediada por el acto de transformar, a través de su domesticación, los poderes genésicos del otro en poderes propios.

Entre los andinos del tiempo de la Conquista, la derrota de un contrario se señalaba, en primera instancia, por el despojo de las prendas de prestigio e identidad soportadas en el cuerpo: los enemigos capturados eran amarrados, desvestidos y pisados, al igual que sus prendas. Todo ello en señal de dominio y victoria: "el pisar o caminar sobre los enemigos muertos o vivos, representaba también un resultado político: una toma de posesión por parte del vencedor sobre el derrotado" (Martínez C. Ms 2015). Tal como lo explica Betanzos:

\begin{abstract}
porque habían de saber que tenían una usanza estos señores que [...] como entrasen los tales capitanes por la ciudad del Cuzco victoriosos e traían delante de si las tales cosas e prisioneros e poníanlas delante de sus señores e los señores viendo el tal despojo e insignias e prisioneros delante de sí levantábase el tal señor e pisábalo e daba un paso por encima de los tales prisioneros y esto hacían los tales señores en señal de que rescibían los tales que los traían en triunfo e favor del señor (Betanzos 1987 [1551]: 35).
\end{abstract}

Estas formas culturales quedaron registradas colonialmente también en imágenes. Guaman Poma, en su Nueva crónica (2008 [1615]: 91), al narrar la derrota de Wascar por los capitanes de Atawallpa, presenta una lámina en que el apresado Inka es llevado descalzo y amarrado de cuello y manos. Es, además, la misma manera de representar la captura y derrota de Tupac Amaru i en el Manuscrito Galvin de Martín de Murúa (2004: 51) (fig. 8). De igual modo, el cuadro anónimo del siglo xviII "La Gran ñusta Chanancoricoca..." muestra la derrota de los chancas por los cuzqueños representando a la ñusta como guerrero victorioso. En la escena, enmarcada por un arcoíris, ella está de pie sobre el cuerpo de un enemigo chanca y ostenta signos de autoridad (como el enano que sostiene una achiwa sobre su cabeza). En una mano sostiene la cabeza cortada y sangrante del enemigo que pisa, mientras que en la otra porta una porra estrellada (fig. 9).

Pues bien, estos modos culturales de ejercer violencia sobre un vencido estaban destinados no solo a evidenciar la derrota, sino también a dominar e incorporar a los enemigos dentro del mundo social y cultural del vencedor. Nuevamente es Betanzos quien nos proporciona estos elementos de análisis. El autor relata cómo Inga Yupangue, tras derrotar a un grupo étnico enemigo, los Soras, pide que los señores capturados sean despojados de sus vestimentas e insignias y 


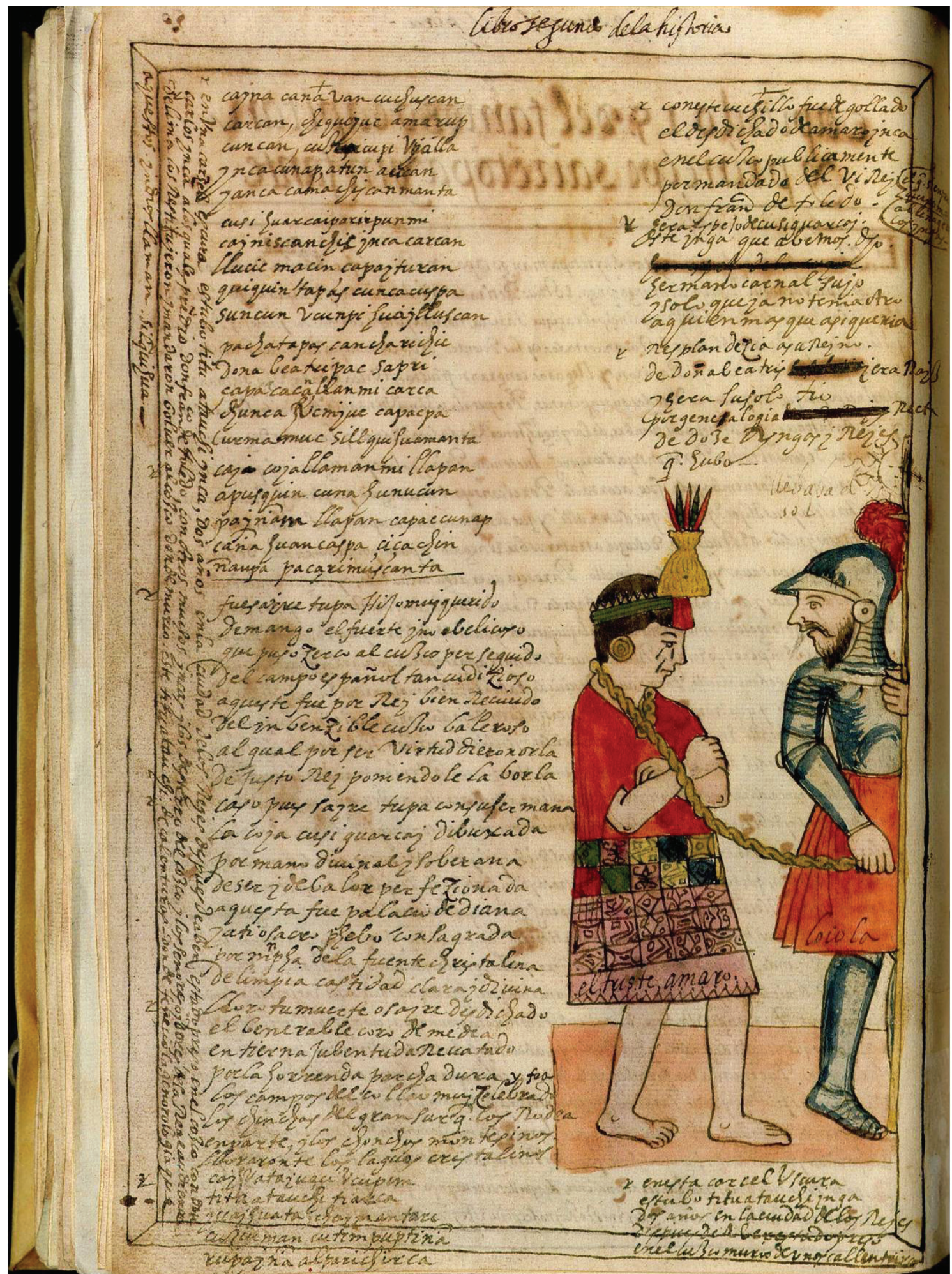

Figura 8. Captura de Tupac Amaru I (Murúa 2004 [1590]: 51). Figure 8. Capture of Tupac Amaru I (Murúa 2004 [1590]: 51). 


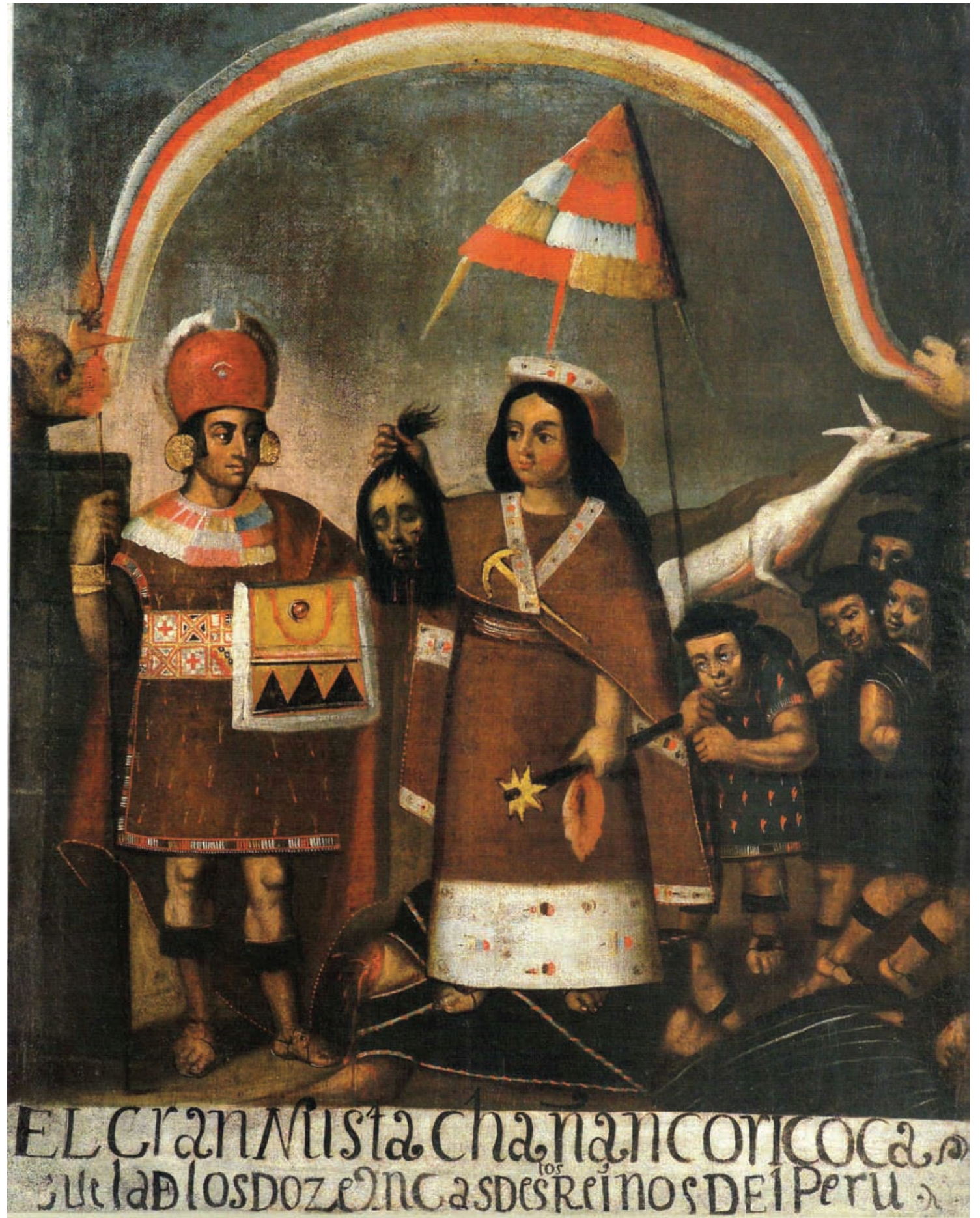

Figura 9. Gran ñusta Chanan Coricoca, siglo xviII (Museo Inka Universidad Nacional de San Antonio Abad del Cuzco). Figure 9. Inka warrior princess "La Gran ñusta Chanancoricoca...", Anonymous painting from 18th century (Museo Inka Universidad Nacional de San Antonio Abad del Cuzco). 
se vistan con unas camisetas rojas que llevaban cosidas borlas rojas: "mandó que fuesen hechas muchas borlas coloradas $[\ldots]$ que las atasen y cosiesen en aquellos vestidos e cosas que allí eran habidas y esto ansí hecho mandólo poner todo debajo de sus pies" (Betanzos 1987 [1551]: 93). Pero no acaba allí, pues luego de hacer vestir a los señores soras estas curiosas camisetas y pisar sus cuerpos y despojos, realiza un último acto de posesión:

... y mandóles echar cierta cantidad de chicha porcima [por encima] y mandóles poner encima de las cabezas ciertas migas hachas de harina de maíz lo cual mandó hacer diciendo que haciendo aquellas cosas ansí aprehendía posesión de los tales señores e pueblos e provincias a ellos sujetos (Betanzos 1987 [1551]: 93, énfasis nuestro. Nótese que echa encima de los cuerpos derrotados de los enemigos chicha y maíz, similar a los procedimientos realizados sobre el cuerpo de fray Diego Ortiz).

¿Qué significados sociales y culturales hay tras estas prácticas: se trata tan solo de causar un daño fisiológico, una humillación? Desde nuestra perspectiva, esta es una construcción cultural de la derrota-violencia que da cuenta de valores y aspectos simbólicos orientados a apropiarse de los poderes productivos del contrario. Así, el otro pasa de planta ajena a planta propia.

El ejercicio de la violencia sobre los cuerpos o la demostración de la derrota de un contrario es una práctica que responde a formas culturales. Dichos modos de hacer varían de una sociedad a otra; se pueden transformar, continúan y cambian en el tiempo, pero siempre en concordancia con una comunidad de sentido que los valida y reproduce (Bourdieu 2007). Se trata de representaciones, prácticas y saberes compartidos y socialmente validados y entendidos. Lo encontramos descrito entre los inkas del tiempo previo a la Conquista (Betanzos 1987 [1551]: 35) y representado en textos visuales durante la Colonia hasta el siglo XviII (qeros coloniales, cuadro "La Gran ñusta Chanancoricoca", etc.). Se trataría de principios generadores y organizadores de procedimientos o habitus que "bajo la forma de esquemas de percepción, de pensamientos y de acción, tienden, con más seguridad que todas las reglas formales y todas las normas explícitas, a garantizar la conformidad de las prácticas y su constancia a través del tiempo" (Bourdieu 2007: 88-89).

La posibilidad de transformar los poderes genésicos de los enemigos en poderes propios, benéficos y productores para la sociedad vencedora está mediada por la violencia, violencia ritualizada y construida como una violencia fecundadora. Creemos que esta idea se puede sostener también desde la etnografía contemporánea. Tristan Platt (1987), en un revelador trabajo sobre el pensamiento político aymara, entrega una serie de ejemplos de herramientas agrícolas que se convierten en armas de guerra, pero además discute los fines que la guerra tendría en la matriz cultural aymara. Esta discusión resulta importante para comprender los significados de la violencia fecundadora sobre cuerpos vegetales que proponemos.

\begin{abstract}
Son varios los conceptos aymaras que relacionan las acciones bélicas con la transformación de una materia prima en objeto cultural. [...] el actor transforma en objeto domesticado una sustancia ajena que se muestra inicialmente recalcitrante. Piedra blanda, tierra de cultivar, metal abollado, animales domesticados; las imágenes comunican los intentos del vencedor de incorporar a los vencidos como componentes de su propio mundo social. [...] Quizás la imagen que mejor expresa esta preocupación es la idea de moler [...] A través de un "molido con golpes" se busca "moler el espíritu" del enemigo, haciéndolo "blando" como la harina en el batán [...] el vencedor en una "cruel guerra" debía mostrarse piedra dura, "amansador", para poder transformar al enemigo "amasado" en harina blanda (Platt 1987: 90-91, énfasis nuestro).
\end{abstract}

Volvamos entonces a los momentos previos a la muerte de Ortiz en Vilcabamba, su trayecto desde Vitcos a Marcanay, trayecto marcado por el ablandamiento de su cuerpo. De acuerdo con Francisco Condorpurri, en declaración del 2 de marzo de 1595:

\begin{abstract}
le prendieron los susodichos que eran capitanes del dicho Inca; $y$ le ataron las manos atrás y le echaron una soga a la garganta y diciéndole muchas palabras de vituperio y que les diese su Inca, le daban muchos palos y mojicones; [...] y luego acabado de decir, le volvieron a prender como la primera vez; y le llevaron camino a Vilcabamba. Todo lo cual vio este testigo por vista de ojos; y que le horadaron los dos carrillos y le metieron por ellos una guasca torcida de hierba cortadera y a manera de freno le tiraban de ella. Vio que de las dichas heridas le salía mucha sangre y se iba el dicho padre quejando ... el cual iba descalzo, sin capilla, ni sombrero; sólo con una saya blanca (Bauer et al. 2014: 73-74, énfasis nuestro).
\end{abstract}

Los procedimientos operados sobre el cuerpo del sacerdote expresan modos de hacer, formas culturales que tendrían un ordenamiento, un lenguaje, una estructura de significar que da cuenta de un sistema de pensamiento en el cual las prácticas se corresponden con valores propios de la cultura. En este caso, desde el supuesto de que plantas y humanos comparten la misma entidad ya desarrollada -o sea, que el cuerpo humano es un 
vegetal-, guerra y agricultura serían la misma práctica, pues implicarían apoderarse de los poderes productores del otro mediante la derrota. Ahora bien, la derrota está mediada por un acto violento, de agresión hacia el otro. Entonces, la muerte violenta sería la derrota del cuerpo, en el caso de guerra, mientras que el cultivo la derrota de la tierra, en el caso de la agricultura.

Si la posibilidad de generar poderes productores pasa o está mediada por el acto violento de apropiación, la tierra es vencida y genera frutos. Los seres humanos, como parte de los vegetales, al ser derrotados y agredidos, ofrecen frutos a los vencedores. Esta parece ser una posible clave de interpretación para una referencia de Betanzos sobre la actitud de Atawallpa frente a ciertos enemigos derrotados en batalla por sus capitanes:

\begin{abstract}
yn volviendo a nuestra historia dicen que como pasase de la provincia de los cañares que fueron presos ciertos indios e señores que él [Atawallpa] mucho deseaba haber y que mandó volver con ellos al sitio do la batalla se había dado y que en un cercado que allí había los enterrasen vivos debajo de la tierra y que fuesen puestos a manera de plantas y árboles bien ansi como cuando lo plantan en los huertos e dijo que había sembrar aquel cercado de gentes de corazones de mala desistión [intención] y que querían ver si producían allí con sus malos frutos y obras y este cercado de gentes mandó que se llamase Collanachacara extremada sementera todo lo cual dicen haber él hecho para memoria de aquella batalla (Betanzos 1987 [1551]: 230, énfasis nuestro).
\end{abstract}

Un problema que nos resulta difícil de abordar es la relación entre ancestros, semillas y cultivos dentro de estas lógicas culturales. Sin embargo, algunas intuiciones nos llevan a pensar que el muerto del propio grupo, al ser también una planta y poseer poderes generativos, es incorporado de manera distinta, no agresiva; es semilla del ayllu, raíz de las personas. El mallqui, como ancestroplanta propia, se siembra en la tierra como semilla de las futuras generaciones. De hecho, la referencia al proceso contra Josefa de la Tica por realizar un rutuchico a su pequeña hija apunta en esa dirección: es una planta propia que se poda para asegurar su crecimiento. Berenguer se ha referido a la posible relación simbólica de las chullpas con el almacenamiento agrícola y el de los muertos: "De hecho, existe información etnográfica en otras partes que señala que la relación entre muerte y fertilidad se halla amplia y profundamente enraizada en la ideología andina, al punto que en algunas aéreas el ritual del entierro se encuentra semántica y conceptualmente vinculado con el cultivar y el plantar" (Berenguer 2004: 133-134).

\section{REFLEXIONES FINALES}

El presente es un trabajo preliminar sobre un tema que debe ser enfrentado con más estudios y análisis, una etnografía que aborde la muerte violenta y sus asociaciones significativas, por ejemplo. Sin embargo, hay algunos elementos que vale la pena considerar de todo lo expuesto. Lo primero es que desde el sistema de pensamiento andino el cuerpo humano es entendido como un vegetal: ambos comparten la misma sustancia y presentan correspondencias anatómicas; como tal, el cuerpo humano participa de los procesos reproductores de las plantas. Desde hace algunos años, los estudios etnográficos y la antropología (Ingold 1996; Viveiros de Castro 2010; Descola 2012) han llamado la atención acerca de otras formas de concebir a las personas humanas y no humanas, muy al margen de la dicotomía que el Occidente moderno ha desarrollado entre naturaleza y cultura. Conforme a esta, donde la clasificación que separa humanos, animales y vegetales no es verosímil, pues las entidades no humanas del medioambiente son consideradas como personas dotadas de capacidades cognitivas, morales y sociales iguales a las humanas: "En muchas regiones del globo, no se concibe que humanos y no-humanos se desarrollan en mundos incomunicables y conforme a principios separados; el medioambiente no se objetiva como esfera autónoma; las plantas y los animales, los ríos y los peñascos [...] no existen en un mismo nicho ontológico definido por su falta de humanidad" (Descola 2012: 64).

Por otra parte, tanto vegetales como humanos, con sus poderes genésicos, deben ser vencidos para luego incorporarse y dar frutos dentro del sistema social y cultural del vencedor. Esta derrota está mediada por actos violentos, por la agresión al oponente: la violencia fecundadora se expresa como cultivo, en el caso de las plantas, y como muerte violenta en el de los humanos. Considerados desde estas reflexiones, los actos cometidos contra fray Diego de Ortiz están llenos de significados culturales: la agresión contra su cuerpo y sus pertenencias no busca solo causar daño fisiológico. Es parte de una construcción cultural, es la violencia que, en términos andinos, da cuenta de esta idea de apropiación de los poderes reproductores del enemigo. Ortiz es entendido como un otro, pero no como un otro distinto: su cuerpo también es un vegetal que se puede plantar e incorporar. 


\section{NOTAS}

${ }^{1}$ En el testimonio, dado en marzo de 1595, de Francisco Condorpuri, otro de los testigos entrevistados en el marco de la investigación por la muerte de fray Diego Ortiz, se lee: "y le metieron en un hoyo, la cabeza abajo y los pies arriba; y le metieron un palo de chonta por el sieso; y le cubrieron con tierra y piedras y le echaron salitre encima y lo dejaron" (Bauer et al. 2014: 74). En el mismo texto, la declaración de Alonso de la Cueva también da cuenta del uso de salitre.

${ }^{2}$ Pisar los despojos de los enemigos vencidos en batalla era parte de las prácticas andinas que denotaban triunfo y dominación. Ver, por ejemplo, la descripción de Betanzos (1987 [1551]: 35) sobre el mismo tema.

${ }^{3}$ Para el quechua, se utilizó el Lexicon o Vocabulario de la lengua general del Perú de Domingo de Santo Tomás (1560); el Anónimo, Vocabulario en la lengua general Quichua (1586) y el Vocabulario de la lengua general de Diego González Holguín (1608). Para el aymara, se consultó el Vocabulario de la lengua Aymara de Ludovico Bertonio (1612). Adicionalmente, se consideró el diccionario Tesoro de la lengva Castellana, o Española de Sebastián de Covarrubias (1611) para comprender mejor algunos términos castellanos y sus usos. El lector puede encontrar un examen más extenso y exhaustivo del vocabulario anatómico en Díaz (2013).

${ }^{4} \mathrm{El}$ diccionario Tesoro de la lengva Castellana, o Española de Sebastián de Covarrubias de 1611 recoge para pimpollo una definición que parece muy sugerente sobre como la lengua española entiende este término: "las puntas del renueuo del arbol: dixose á pululando. Otros quieren se aya dicho quasi pino pollo, quando es nueuo", mientras que para renueuo tenemos, "los nueuos vastagos que echa el arbol podado, o cortado" (Covarrubias 1977 [1611]: 588).

${ }^{5}$ El ulluco, conocido también como "papa lisa", es un tubérculo originario del altiplano andino. Tanto la raíz como las hojas son comestibles.

${ }^{6}$ La racacha, arracacha o "zanahoria blanca" es una planta alimenticia originaria de los Andes que pertenece a la familia de las apiáceas, como la zanahoria y el apio.

7 "Pares. Es aquella piel en que el niño ha estado embuelto en el vientre de su madre, que en naciendo sale luego tras él, latine secundae, arum" (Covarrubias 1977 [1611]: 852).

${ }^{8}$ Debido a restricciones de espacio, no se desarrolla aquí el concepto cristiano-occidental del cuerpo, pero el lector puede remitirse a las obras de Le Breton $(1990,1999)$.

${ }^{9}$ La tradición oral andina contemporánea recoge otras mutilaciones como origen de los alimentos. Uno de los relatos más conocidos es el del zorro despedazado (Itier 1997; La Riva González 2005).

${ }^{10}$ Durante los meses que no son de lluvia, estas cruces son depositadas sobre los costales que guardan las cosechas, trigo, maíz u otras y a menudo a los pies de las camas, en el dormitorio. Se dice que estas cruces hacen que la cosecha sea suficiente para todo el año (Verónica Cereceda, comunicación personal).

${ }^{11}$ Lo más interesante es el hallazgo en contexto arqueológico de una de estas piezas alrededor de 1867 (Salomon, Feltham \& Grosboll 2010). Ello estaría señalando una práctica ritual en que se utiliza cabezas extraídas de héroes o enemigos como trofeos de guerra que permiten apoderarse de la fuerza del vencido.

${ }^{12}$ Nos referimos a la serie de piedras de granito grabadas de estilo figurativo que muestran guerreros, partes de cuerpos humanos seccionados y especialmente cabezas decapitadas.
${ }^{13}$ En un trabajo anterior, desarrollamos en mayor profundidad la presencia del motivo "cabeza decapitada" en el registro iconográfico prehispánico y colonial (Díaz 2013).

${ }^{14}$ En el Museo Arqueológico de la Oficina María Elena (II Región, Chile) se conserva un cuerpo momificado que presenta cráneo con cabello trenzado y extremidades inferiores en cuclillas; el tronco, en cambio, está conformado por maíces. No parece un sacrificado, sino un ancestro en el sentido expresado por Frame (2001) sobre la semejanza a la siembra de muertos o ancestros, los que tendrían injerencia en la productividad de los campos en el alcance propuesto por Berenguer (2000). Otro cuerpo momificado, el "Niño de maíz", del mismo museo, un menor de edad enterrado con herramientas de labranza agrícola amarradas a sus manos, sugiere lo mismo.

\section{REFERENCIAS}

Allen, C., 1988. The hold life has: Coca and cultural identity in an Andean community. Washington DC-Londres: Smithsonian Institution Press.

Alva, W. \& C. Donnan, 1993. Tumbas reales de Sipán. Los Angeles: Fowler Museum of Cultural History.

Anónimo, 1951 [1586]. Vocabulario y phrasis en la lengua general de los indios del Perú, llamada Quichua. Ed. facsimilar. Lima: Instituto de Historia, UNMSM.

Bauer, B.; T. Aparicio, J. Galiano, M. Halac-Higashimori \& G. Cantarutti, 2014. Muerte, entierro y milagros de fray Diego Ortiz. Política y religión en Vilcabamba, s. XVI. Cuzco: Ceques.

Berenguer, J., 2000. Tiwanaku. Señores del lago sagrado. Santiago: Museo Chileno de Arte Precolombino.

Berenguer, J., 2004. Caravanas, interacción y cambio en el desierto de Atacama. Santiago: Museo Chileno de Arte Precolombino.

Bertonio, L., 1984 [1612]. Vocabulario de la lengua Aymara. Cochabamba: CERES-IFEA-MUSEF.

Betanzos, J. de, 1987 [1551]. Suma y narración de los Incas. M. C. Martín Rubio, Ed. Madrid: Atlas.

Bourdieu, P., 2007 [1980]. El sentido práctico. Buenos Aires: Siglo xxi. Cieza de León, P., 1996 [1553]. Crónica del Perú, Segunda Parte. Lima: Pontificia Universidad Católica del Perú.

Covarrubias, S. 1977 [1611]. Tesoro de la lengva Castellana, o Española. Madrid: Turner.

De LA VegA, G., 2005 [1609]. Comentarios reales de los Incas. México: FCE. Descola, P., 2012. Más allá de naturaleza y cultura. Buenos Aires: Amorrortu.

DíAz, C., 2013. Violencia y reproducción. La cabeza decapitada en los discursos andinos coloniales (siglos XVI-XVIII). Tesis para optar al grado de Magíster en Historia, Mención Etnohistoria, Universidad de Chile.

Duviols, P., 1993. Estudio y comentario etnohistórico. En Relación de antigüedades deste Reyno del Perú, J. de Santa Cruz Pachacuti, pp. 15-126. Cuzco: IFEA-Centro de Estudios Regionales Andinos Bartolomé de Las Casas.

Fernández de Oviedo, G., 1959 [1535]. Historia general y natural de las Indias. Madrid: Atlas.

FRAME, M., 2001. Blood, fertility, and transformation: Interwoven themes in the Paracas necrópolis embroideries. En Ritual sacrifice in ancient Peru, E. Benson \& A. Cook, Eds., pp. 55-92. Austin: University of Texas Press. 
Gallardo, F., 1996. Donde la muerte es vida: iconografía Nasca y simbolismo. En Nasca. Catálogo de exposición. Santiago: Museo Chileno de Arte Precolombino.

González Holguín, D., 1989 [1608]. Vocabulario de la lengua general de todo el Perú llamada Lengua Qquichua o del Inca. Lima: Universidad Nacional Mayor de San Marcos.

González, E., 2003. Ritos de tránsito en el Perú de los Incas. Lima: IFEA-Lluvia.

Guaman Poma de Ayala, F., 2008 [1615]. El primer nueva corónica $y$ buen gobierno. Lima: FCE.

Hemming, J., 2005. La conquista de los Incas. México: FCE.

INGOLD, T., 1996. Hunting and gathering as ways of perceiving the environment. En Redefining nature: Ecology, culture and domestication, R. Ellen \& K. Fukui, Eds., pp. 117-156. Oxford: Berg.

IsBell, B. J., 1997. De inmaduro a maduro: lo simbólico femenino y los esquemas andinos de género. En Más allá del silencio. Las fronteras de género en los Andes, D. Arnold, Ed., pp. 253-298. La Paz: CIASE-ILCA.

ITIER, C., 1997. El zorro del cielo: un mito sobre el origen de las plantas cultivadas y los intercambios con el mundo sobrenatural. Boletín del Instituto Francés de Estudios Andinos 26 (3): 307-346.

Jiménez, A. \& L. Samaniego, 1973. Guía de Sechin. Perú: Ordeza.

LA Riva GonzÁlez, P., 2005 El zorro mutilado, el zorro despedazado. Reflexiones sobre las representaciones de la fertilidad en los Andes meridionales del Perú. En Etnografías del Cuzco, A. Molinié, Ed., pp. 19-45. Cuzco: IFEA-CBC.

Le Breton, D., 1990. Antropología del cuerpo y Modernidad. Buenos Aires: Nueva Visión.

Le Breton, D., 1999. Antropología del dolor. Barcelona: Seix Barral.

MartíneZ, J. L., 2015 Ms. Narraciones andinas sobre los inkas de Vilcabamba: cantares, representaciones y textos visuales. Proyecto FONDECYT 1130431.

Martínez, R., 2010. La música y el Tata Pujllay: carnaval entre los Tarabuco (Bolivia). En Diablos tentadores y pinkillos embriagadores, G. Arnaud., Ed., pp. 143-181. La Paz: Plural-UATF.
Murúa, M., 2004 [1590]. Historia y genealogía de los Reyes Incas del Perú del padre mercedario fray Martín de Murúa (Manuscrito Galvin). J. Ossio, Ed. Madrid: Testimonio.

Nielsen, A., 2007. Armas significantes: tramas culturales, guerra y cambio social en el sur andino prehispánico. Boletín del Museo Chileno de Arte Precolombino 12 (1): 9-41.

Pachacuti, J., 1993 [1613?]. Relación de antigüedades deste Reyno del Perú, P. Duviols \& C. Itier, Eds. Cuzco: IfEA-Centro de Estudios Regionales Andinos Bartolomé de Las Casas.

Platt, T., 1987. Entre chaxwa y muxsa. Para una historia del pensamiento político Aymara. En Tres reflexiones sobre el pensamiento andino, pp. 61-125. T. Bouysee-Cassagne, V. Cereceda, O. Harris \& T. Platt. La Paz: HISBol.

Platt, T., 2010. Desde la perspectiva de la isla. Guerra y transformación en un archipiélago vertical andino: Macha (norte de potosí, Bolivia). Chungará 42 (1): 297-324.

Rostworowski, M., 1992. Pachacamac y el Señor de los Milagros. Una trayectoria milenaria. Lima: Instituto de Estudios Peruanos.

Ruiz de Navamuel, A., 1904 [1572]. En La imprenta en Lima (15841824), tomo I, J. T. Medina, pp. 182-187. Santiago: Impreso y grabado en casa del Autor.

Salomon, F.; J. Feltham \& S. Grosboll, 2010. La revisita de Sisicaya, 1588. Huarochirí veinte años antes de dioses y hombres. Lima: PUCP.

SAmAnIEgo, L., 1980. Informe sobre los hallazgos en Sechín. Indiana 1: 307-327.

SAnto Tomás, D. de, 1951 [1560]. Lexicon o Vocabulario de la lengua general del Perú. Lima: Instituto de Historia, UNMsm.

TAYLOR, G., 2008. Ritos y tradiciones de Huarochirí del siglo XVII. Lima: Instituto de Estudios Peruanos.

Topic, J. \& T. LANGE, 1997. Hacia una comprensión conceptual de la guerra andina. En Arqueología, Antropología e Historia en los Andes. Homenaje a María Rostworowski, R. Varón \& J. Flores, Eds., pp. 567-590. Lima: Instituto de Estudios Peruanos-Banco Central de Reserva del Perú.

Viveiros de Castro, E., 2010. Metafísicas caníbales. Madrid: Katz. 